\title{
Information - is it Subjective or Objective?
}

\author{
Andrzej S. Zaliwski \\ Institute of Soil Science and Plant Cultivation - State Research Institute \\ Czartoryskich 8 \\ 24-100 Putawy Poland
}

\begin{abstract}
The article deals first with the problems of defining information. It is concluded that it is a misunderstanding to take a term and then to look for a definition. Rather a different way ought to be taken: to find the phenomenon first and then assign a name to it. The view that information is the same thing as a structure is considered. Then the processes by which information is created are analyzed. The definition that information is detected difference is closely scrutinized and it is found that information can also be detected sameness. It is argued that information is relative to the observer and for the very reason of the way it is created it is subjective. That extends only to information acquired. The existence of subjective information, however, does not prove information cannot exist objectively.
\end{abstract}

Keywords: information, theory, ontological category, definition, acquisition, processing

Acknowledgement: The article springs from a further development of theoretical deliberations undertaken in order to analyze certain concrete information issues encountered within the project "Advisory systems in sustainable plant production". The project is part of the five-year program "Shaping the Polish Agricultural Environment and Sustainable Development of Agricultural Production", financed by the Ministry of Agriculture and Rural Development of the Republic of Poland.

For those who want to learn something on the notion of information there are some in-depth sources covering the origin of the term and its history, e.g. Capurro (2009) or Błasiak and Koszowy (2010). However, persons looking for a definition of information will be baffled if not discouraged by the sheer number of different definitions existing side by side in the literature. Samples of this variety can be found e.g. in Kowalczyk (1981), Flückiger (1995), Floridi (2004), Michałowski (2007), Zins (2007), Łapiński (2008), Bates (2010), Burgin (2010) and Lenski (2010). A. M. Schrader (1983) found about 700 information definitions in the context of information science alone (as cited in Lenski, 2010, p. 108). The total number of definitions to be found in the relevant literature sources can possibly be really impressive. What may be the cause of this cornucopia?

Mazur (1970, p. 14) explains the way concepts are defined in science in this way:

a) first a research problem is analyzed,

b) than relevant concepts are defined,

c) after that a convenient term is selected for each definition.

Perhaps this could account for the number of definitions - research problems that take information into account are innumerable.

Some authors try to introduce order to this terminological chaos by developing classifications of information notions and definitions. A rather exhausting one was presented in D. Nafría (2010). He enumerated three approaches to information depending on how it is viewed: dimensional (syntactical, semantic, pragmatic, etc. dimensions), domain-specific (stemming from the scientific discipline within which it was developed) and ontological-epistemological (taking into account the ontological and epistemological categories involved).

Another way is to try to investigate the matter in depth in order to find some fundamental concept of information applicable to all situations. This means undertaking efforts to elaborate 'a grand unified theory of information', as L. Floridi (2004, p. 563) put it. In fact efforts of that kind 
were undertaken. For instance, A. Chmielecki (2010) investigated a basic concept of information within the field of philosophy. He claimed: "In my opinion it is possible to determine the fundamental concept of information. As fundamental for other concepts of information as elementary particles are fundamental for every physical object, or as the foundation is fundamental for the building" ( $p$. 1). The detailed explanation of that fundamental concept of information and its ramification is in Chmielecki (2001). Another researcher, M. Burgin (2003; 2010, pp. 52-254) developed a General Theory of Information that unifies a number of existing information theories by treating them as special cases.

So much progress has been made in the theory of information since the publication of Shannon's work in 1948 (Shannon, 1948) that a short article like the present one can only touch the surface of the pyramid of knowledge here and there. To chose one aspect means therefore to omit others. It seems the most fruitful way will be to start the analysis of information with its occurrence and acquisition. In ontological terms information can occur e.g. as a physical entity something existing objectively, independently of any observer, or as a subjective entity, created only by the human mind.

\section{Objective and subjective information}

The problem of objectivity and subjectivity of human knowledge has a long tradition and can be traced to Greek philosophers such as Plato and Aristotle. In their modern usage the terms "objectivity" and "subjectivity" relate generally to a perceiving subject (normally a person) and a perceived or unperceived object (Mulder, 2004).

In order to penetrate deeper into the matter of information objectivity-subjectivity it is not necessary to go back in time further than the origins of the modern concept of information. According to P. Young (1987) the common usage of the word 'information' in science did not begin until the late 1940s and early 1950s. Only since then it has begun to appear in many scientific areas. As the underlying causes he gave the following three facts (pp. 5-6):

d) the publication in 1948 of "A Mathematical Theory of Communication" by Claude Shannon (Shannon, 1948), which seemed to give to the concept of information a rigorous, mathematical grounding (in fact it did not, because it dealt only with the 'amount of information' and not with information per se),

e) the mathematical similarity of information and entropy, which suggested a relation between Shannon's theory and physics,

f) the use of the term 'information' in connection with the early computers of 1940s.

There are other literary sources maintaining a similar view on the origin of the modern concept of information, e.g. Bates (2010) or Logan (n.d.). Shannon's theory determines the minimal resources sufficient for successful communication, which takes place when the message sent is received and successfully reproduced. The message exists objectively, therefore information in Shannon's theory is treated objectively (Saab and Riss, n.d., p. 4). However, Shannon's information concept concerns only symbols used for information transmission. The intuitive notion of information goes together with the concepts of meaning and knowledge and this fact led to the criticism of Shannon's quantitative view of information. Donald Mackay at the 8th Macy Conference held on 15-16 March 1951 (American Society for Cybernetics, 2008) presented arguments for the necessity of incorporating meaning into the concept of information. According to N. K. Hayles (1999, p. 74), Mackay's proposition was to define information as "the change in a receiver's mindset" (as cited in Logan, n.d.). Relating information to the mind suggested its subjectivity which was not acceptable to many researchers. These two approaches (sticking to the research areas where information objectivity could be kept or including the meaning for the price of losing the objectivity) divided the researchers into two camps. As a result a number of authors elaborated information theories of 
their own that included, if not meaning, at least some qualitative features of information. P. Rocchi (2010, p. 2) quoted a number of qualitative information theories elaborated in the years 1953-2003.

The concept of information discussed till now may be characterized as the cyberneticists' view of information. The term 'cybernetics' was proposed by a group of scientists (Norbert Wiener and Arturo Rosenblueth with his team) to stand for the entire field of control and communication theory as applied to the machine and the animal (Wiener, 1948, p. 11). As control circuits exist both in living and artificial systems so does information.

However, the objectivity of information may also have another dimension. As an example Stonier (1996) may be cited, who claimed: "The new information theory proposed assumes information to be a basic property of the universe - as fundamental as matter and energy." (p. 136). Since the time these words were written, some work has been done to develop the assumption into a physical theory (e.g. Bekenstein, 2003; Fuchs, 2003).

Harbingers of such a concept of information can be found in earlier works. For instance M. Mazur (1966) suggested that information and structure (organization of matter) are identical entities: "structure is information and change in structure is information processing" (p. 49).

a)

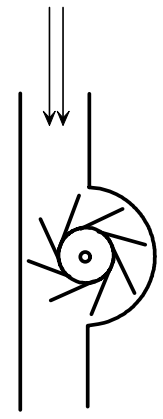

b)

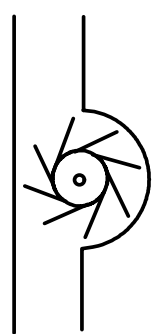

c)

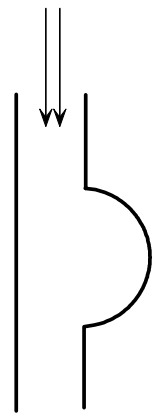

d)

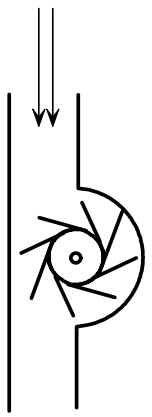

Figure 1: Water turbine. Differentiation of: a) energy, b) matter, c) and d) structure (Mazur, 1966, p. 47)

As a proof he provided the argument illustrated in fig.1. It shows a water turbine viewed as a combination of three elements: energy (water flow), matter (turbine rotor and stator) and structure (the turbine is assembled according to the rules of art). In fig.1a) the turbine works correctly as the three elements are in place. In b) and c) the turbine does not work because either energy or matter is missing. In d) the turbine does not work (properly) because the structure is wrong - information on mounting the rotor is incorrect. This example is suggestive but not decisive - can we put the sign of equality between structure and information?

C. F. von Weizsäcker (1978) wrote as early as 1969 (as the translator reported on p. 404):

Information of some situation is simply the number of pre-alternatives that constitute the situation. According to the simplest model of the particle with mass, its rest mass is the number of pre-alternatives necessary to build the particle at rest, i.e. it is equal to the information invested in the particle. (p. 428)

Exploration along the same lines was pursued by other researchers, too. According to V. V. Gorshkov, V. G. Gorshkov, Danilov-Danilyan, Losev and Makareva (2002) information incidence extends to all objects, animate and inanimate (natural and artificial). They introduced the concepts of 'degrees of freedom' or 'memory cells' (equivalent to Weizsäcker's 'pre-alternatives'), which can be regarded as differentiation of structure. In physical processes (such as wind, avalanches, precipitation or water vortices) information is carried by macroscopic memory cells and in the living organisms by molecular memory cells - DNA (p. 151). They calculated the memory capacity of the molecular memory cells to be twenty orders of magnitude higher than the macroscopic ones. 
A lot of work has been done to explain the nature of information meaning since the Macy conferences. The statement that information can be subjective is taken for granted in science. Again Weizsäcker (1978, p. 431) can be quoted: "According to our way of thinking matter is nothing else than a possibility of resolving alternatives empirically. The subject, who resolves these alternatives, is assumed". In fact statements like "As a matter of fact, only the human mind can create information, since even the most precious message sent to a recipient, but not understood, will trigger off no reaction - no information will be received" can be found now not only in works on psychology, but also in strictly technical handbooks, e.g. on "Systems engineering" (Jaros \& Pabis, p. 55).

\section{Acquisition of information}

In the previous chapter some light was shed on the possible approaches to information occurrence. The very way of its occurrence makes it subjective or objective. In order to clarify these matters the ways in which information is created will be scrutinized.

As the concept of information is closely related to that of knowledge, and the theory of knowledge has a much longer tradition, the sources of knowledge will be reviewed next. M. Steup (2010) wrote from the standpoint of philosophy with regard to knowledge: "For true beliefs to count as knowledge, it is necessary that they originate in sources we have good reason to consider reliable. These are perception, introspection, memory, reason, and testimony".

Perception means perceiving the world "through our five senses". As senses begin with receptors this could be understood as "through receptors". Introspection is the capacity to "feel" and "see" "inside" of the mind. This is realized by the inner receptors. In the memory the knowledge acquired in the past is retained. This knowledge may be from the previous two sources or the two that follow (reason and testimony). Reason in the philosophical tradition is suggestive of two sources of knowledge. The first one is from experience (a posteriori knowledge), which is based on the information from the inner and outer receptors. The second one solely comes from the use of reason (a priori knowledge). Testimony comprises communication, which in broad terms consists in copying the existing information.

If we pass over the issue of a priori knowledge (which is in fact debatable and does not fit the present study - in the same sense as meaning did not fit the Shannon's theory), we are left with the following sources of information (assuming that all knowledge is based on information, which might be a simplification, nevertheless we are building a model):

a) from receptors (or broadly speaking extracted from the inner and outer environment with the aid of receptors and other detectors, e.g. those in measuring devices),

b) from inference - extracted additionally by reason.

A similar simplification was made e.g. by Devlin (1991, pp. 10 \& 16). Again, since information from inference is a very broad topic, it is inevitable to narrow the scope of the analysis essentially to the information brought out by detectors from the environment or "physical reality", a term used by Rocchi (2010, p. 4): "Common literature accepts that measurement is the method to acquire information from the physical reality".

In order to investigate the information acquisition by a sensor a simple control system is used (fig.2). The system controls water level in a tank. The function of the device is apparent from the figure a): if the water level rises in the tank, the water closes the electric circuit and the valve is started which cuts off the in-flow of water into the tank. If the water level drops the valve is opened again (water out-flow from the tank is not shown). 
a)

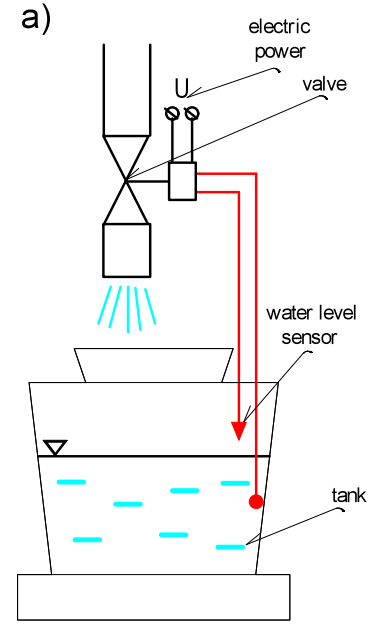

b)

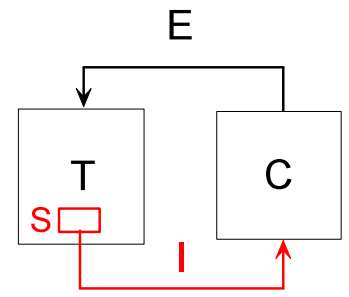

Figure 2: Control circuit: a) functional diagram of control system, b) energy and information flow in control system. Notation: T - tank, S - sensor, C - control system, I - information, E - energy.

In order to find out more about the functioning of a device, Jaros and Pabis (2007) recommended to model the "empirical system" (p. 17). The model should retain sufficient similarity with regard to the purpose of modeling. Our purpose is to find the principle of information generation in a sensor, so the model should show the sensor and the information flow. In fig. $2 \mathrm{~b}$ the modeling situation is shown. Obviously, some modeling method is needed to explore the inner complexity of the information flow in the sensor. It may be rightly expected that such a method is to be found in the domain of Information Theory. As the problem is of qualitative character the search can be narrowed to qualitative information theories.

Especially useful in the analysis of information flows can the Qualitative Information Theory authored by the Polish cybernetician M. Mazur (1970). A description of it can be found in M. Burgin (2010, pp. 455-461). Z. Gackowski (2010, pp. 41-43) also gave a short account of Mazur's theory. However, to make the present article consistent and considering that there exists no English translation of Mazur's original work, the necessary basics are outlined below. The situation from fig. $2 b$ modeled in terms of Mazur's theory is portrayed in fig.3. It is a further abstraction of the control system, where only information flow is presented, but in detail.

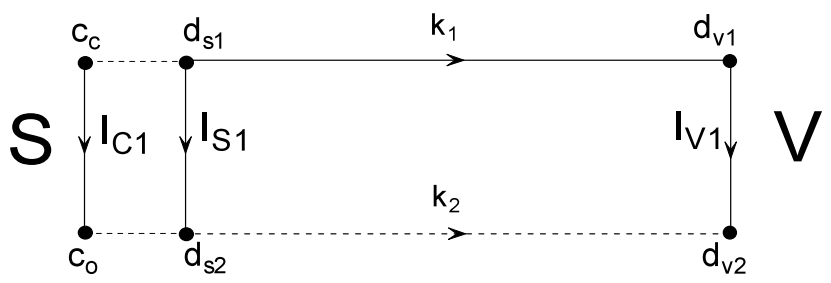

Figure 3: Information channel: $\mathrm{S}$ - sensor, $\mathrm{V}$ - valve, $\mathrm{c}_{\mathrm{c}, \mathrm{o}}-$ states of sensor, $\mathrm{d}_{\mathrm{s} 1,2}-$ data sent by sensor, $d_{\mathrm{v} 1,2}-$ data received by valve, $I_{\mathrm{C} 1}-$ information created in sensor, $I_{\mathrm{s} 1}-$ information sent by sensor, $\mathrm{I}_{\mathrm{V} 1}$ - information received, $\mathrm{k}_{1,2}$ - codes.

The sensor in the control system is of the simplest kind. It has a contact which, when touched by the water, closes the electric circuit, and when the water abates, opens it. These two physical events create two states of the sensor, depicted in fig. 3 as $c_{c}$ (circuit closed) and $c_{o}$ (circuit open). The question is: where and when is information created? The movement of water with regard to the contact produces a great number of states but only two of them are relevant from the viewpoint of 
the water level control. The sensor is built so as to discover only these two states and to neglect all the others. It can only detect the water touching the contact or not touching it. The moment of detection occurs when the electric current starts or stops to flow. These two states cause data $d_{s 1}$ and $d_{s 2}$ to appear (fig.3). The data are in fact another pair of physical states: a state when the electric current flows and when it does not. According to Mazur (1970, p. 70) a transformation between two physical states is called information, so we can write: $d_{\mathrm{s} 1}=I_{\mathrm{s} 1} \cdot d_{\mathrm{s} 2}$. As Mazur pointed out (p. 41), transformation should be treated here as an analog to relation. He chose the term "transformation" in his theory for the sake of intelligibility: it can be either a mathematical formula binding two data or an association between two data (e.g. a database relation).

The sensor can create two pieces of information, because $d_{s 1}$ can be transformed into $d_{s 2}$, but the reverse is also possible, i.e. $d_{\mathrm{s} 2}$ can be transformed into $d_{\mathrm{s} 1}$. Figure 3 shows only the first case. The other piece of information that can be obtained in this way is called simply reverse information. The impulses of the electric current sent along the circuit to the valve cause a similar pair of states to occur there. These are the faithful images of the original states. Thus information is re-created at the valve in the form of the transformation of $d_{v 1}$ into $d_{v 2}$. In order to activate the valve, it has to be amplified as a rule. This means that the signal sent to the valve in power terms may be the smallest possible, but not zero, as there has to be a difference between the data $d_{s 1}$ and $d_{s 2}$.

In fig. 3 codes $k_{1}$ and $k_{2}$ are also marked. All the possible water levels are translated by the sensor into only two states: the levels lower than the contact and the levels when the water touches the contact (it is even with the contact or above it). These two states are the system of knowledge of the sensor (thesaurus) through which it sees the world (Burgin, 2003, p. 153). The states are recognized by the sensor when they are encoded, i.e. they become the data $d_{\mathrm{s} 1}$ and $d_{\mathrm{s} 2}$ and then as the electrical impulses they can be transmitted along the control channel. It should be noticed that the datum $d_{s 2}$ is not sent in the form of an impulse but as a lack of impulse. Although nothing is sent in the physical sense, the information is re-created $\left(d_{v 1}\right.$ is transformed into $\left.d_{v 2}\right)$ when, after an impulse, comes a period of stillness.

What is it that the sensor detects? Well, it simply detects the existence of one of the states. To put it in other words: from the moment the signal starts to be transmitted the state the water touches the contact' exists, and from the moment the signal stops to be transmitted the state 'the water does not touch the contact' exists.

\section{How does information arise?}

Perhaps this is the best moment to coin some working concept of information that would emphasize detection - a definition reflecting the information acquisition in detectors. It seems that G. Bateson (1972, p. 272) looked for such a definition, when he stated: "information may be succinctly defined as any difference which makes a difference in some later event". He went on to say: "the differences (...) are first transformed into differences in the propagation of light or sound, and travel in this form to my sensory end organs" (p. 321). In short, "information is the difference in the environment 'received' by a sensor".

In Chmielecki (2001, p. 34) a definition strikingly similar to that of Bateson's can be found, with the accent transferred on the detection of the difference, which is given explicitly: "information is detected difference". According to Chmielecki (1998) "Information is a distinct, objective entity. 'Difference' and 'detection' are two key words in grasping what information is. To become information some objectively occurring difference must be detected by some system". Chmielecki's definition can be viewed as a perfected version of Bateson's theory and because of that it will be selected for further investigation.

In order to grasp the concept of information, Chmielecki (2001, pp. 12-28) developed an ontology, entertaining a conviction that when the whole reality were divided into parts, information would fall into one of them - thus it would become apparent. He introduced sets of various classes of beings, from species (lowest-level sets) to categories (highest-level sets). He arrived at the conclusion that information is a category - i.e. the highest-level super-ordinate class, not contained in any other class. Being a difference it is immaterial (abstract, intangible), because it is a relation 
(p. 33). Yet it needs a material carrier - since a difference is always a difference between some physical states (p. 35). Information can only be acquired by receptors (natural detectors of difference) or sensors (man-created detectors of difference). In nature it is therefore exclusive solely to living organisms. Once created it can be used, e.g. in control circuits of living organisms or artificial devices (p. 36).
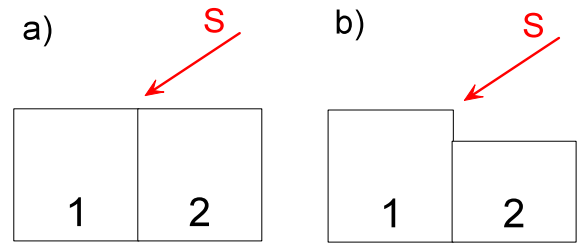

Figure 4: Detection of difference: a) no difference exists, b) a difference exists, $S$ - sensor, 1,2 real objects.

The detection of a difference is portrayed in fig.4. With a combination of two elements four cases are possible:

a) no difference exists objectively: the sensor detects no difference or detects a difference,

b) a difference exists objectively: the sensor detects a difference or detects no difference.

If no difference exists (a), the sensor of course should detect no difference, but sometime something goes wrong - and then the sensor shows the presence of a difference. The detection of an existing difference depends on the resolution of the sensor. A difference smaller than the resolution limit cannot activate the sensor - it is "not noticed". Nevertheless, if it is found to exist, it does exist objectively, otherwise it would evade detecting.

As has been said previously, sensors have thesauri that determine their resolution. E.g. the water level sensor can distinguish only two states (its thesaurus is binary). Because of that it "generalizes" the differences found in the real world - everything below its resolution.

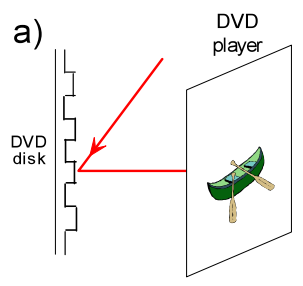

b)

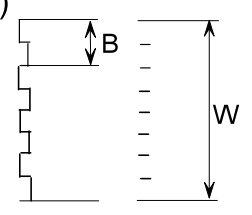

Figure 5: Thesaurus of DVD player: a) real situation, b) alphabet and words, $B$ - binary alphabet, $\mathrm{W}$ - range of word.

A thesaurus can be of course more complex, as illustrated in fig. 5. From Alleman (2000) we can learn that on the DVD disk there are only two states written: "bumps" and "pits" for the laser to read (fig. 5a). However, that is not the thesaurus of the DVD player that reads the disk but only its "binary alphabet". From this alphabet the DVD player sets longer "words", e.g. words of 32 "bumps" and "pits" - 32 bit words of the thesaurus. The possible number of different words in such a thesaurus is quite impressive. For instance, it is possible to create $2^{32}$ words 32 bits long - over 4 billion.

The reading of a DVD disk is a situation very different from the water level sensor behavior also in another important aspect (besides the alphabet) - that is to say the resolution of the disk is the 
same as the resolution of the player, so no "generalization" is necessary. This is inherent, in fact, in communication channels, where information is only transmitted (copied) and not acquired from the environment. However, here also the existence is detected: the existence of bumps and pits in the first instance and then of the words.

The "binary-alphabet" technology is used of course also in control channels. Mazur (1966) indicated that "control and information processing is one and the same thing, as no control is possible without information processing and information is used exclusively for control" (p. 11). For this reason "control channels" and "communication channels" can be called by one general name "information channels".

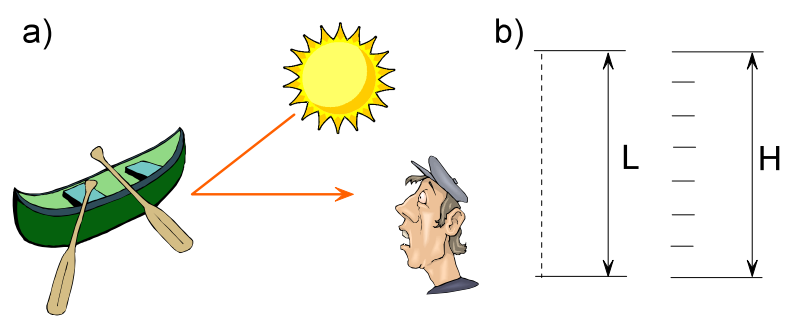

Figure 6: Comparing thesauri: a) real situation as seen by man, b) range of thesauri, $L-$ range of light thesaurus, $\mathrm{H}$ - range of human thesaurus.

In fig. 6 a still more complex situation is presented. A real object, a boat, is being perceived by a man. Assuming that the sunlight has a thesaurus, it is very impressive not only in its color spectrum but also in the number of the photons sent. The information acquisition processes in the human vision system are extremely complex. H. Kolb (2003) described its first stages: The retina includes the photoreceptors (sensory neurons) that respond to light and intricate neural circuits that perform the first stages of image processing; ultimately, an electrical message travels down the optic nerve into the brain for further processing and visual perception (p. 28).

Photoreceptors have pigment-bearing membranes. The photons strike pigment molecules and excite them. The decomposition of images into separate parts begins right in the photoreceptors. Gleitman (1991) reported that there are about 126 millions photoreceptors in each human eye (as cited in Maruszewski, 2001, p. 77). A photoreceptor may receive thousands of photons each second. Mazurek (2001, p. 31) stated that there are two kinds of photoreceptors: rods and cones, forming a mosaic in the retina. Cones provide color vision and visual acuity and rods vision in dim light. Their sensitivity makes it possible to detect even a single photon, compared to about 100 photons for cones (p. 34).

Some details on the nervous system were given by Farabee (1992). Kolb, Fernandez and Nelson (2010) provided an excellent account on the vision system.

The generalization process in a rod according to Mazur's theory (Mazur, 1970, pp. 121-125) may look like shown in fig.7. 


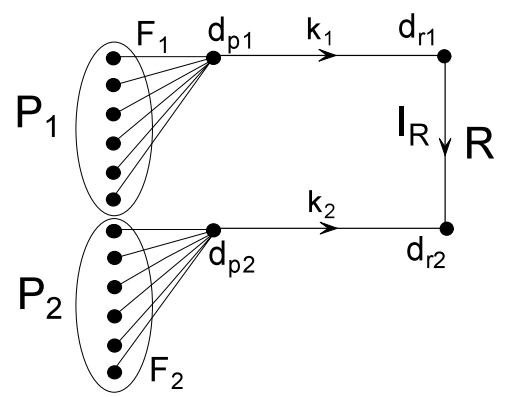

Figure 7: Information generalization in rod cell: $P_{1,2}-$ pigment molecules, $R-\operatorname{rod}, F_{1,2}-$ photon sets, $d_{p 1,2}-$ data sent to rod, $d_{r 1,2}-$ data received by rod, $I_{R}$ - information created by rod, $k_{1,2}-$ codes.

Visual pigment molecules $P_{1}$ and $P_{2}$ receive sets of photons $F_{1}$ and $F_{2}$. By generalizing and encoding them, the data $d_{p 1}$ and $d_{p 2}$ are obtained. These data are then sent to the rod R. The neuron creates information $I_{R}$ from the data received $\left(d_{r 1}\right.$ and $\left.d_{r 2}\right)$.

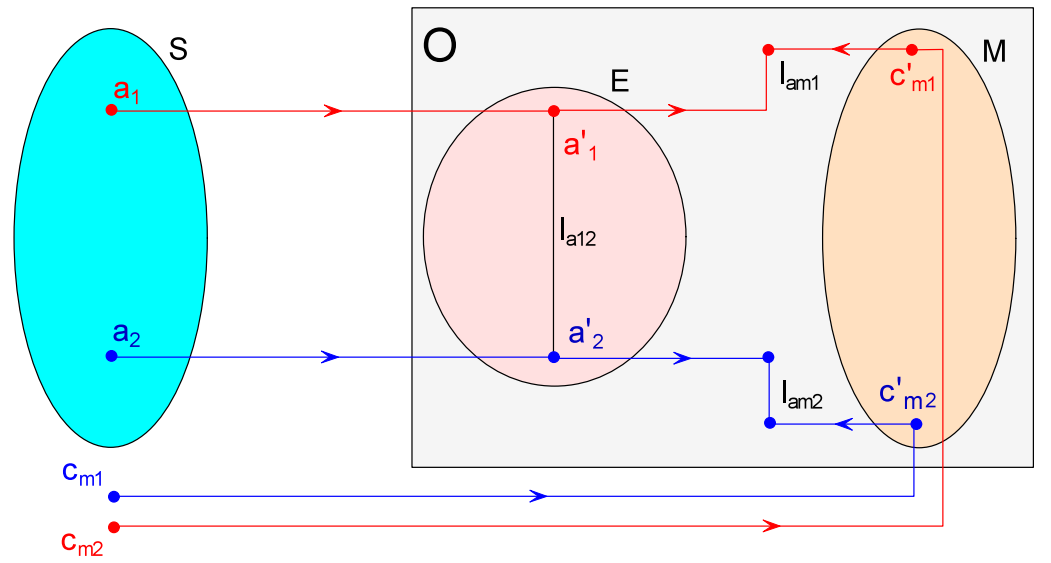

Figure 7: Detection of colors in the sky by a human observer: $\mathrm{S}$ - sky, $\mathrm{O}$ - observer, $\mathrm{E}-$ eye, $\mathrm{M}$ memory, $a_{1,2}-$ color areas observed, $a_{1,2}-$ images of areas observed, $\mathrm{l}_{\mathrm{a}_{12}}-$ information from areas observed, $\mathrm{c}_{\mathrm{m} 1, \mathrm{~m} 2}$ - colors observed, $\mathrm{c}_{\mathrm{m} 1, \mathrm{~m} 2}$ - colors remembered, $\mathrm{l}_{\mathrm{am} 1, \mathrm{am} 2}$ - information created from data observed and remembered.

In the figure 8 a diagram of the process of detection of colors in the sky is presented. Two areas are assumed to be observed: one as "reddish" and the other as "bluish" in color $\left(a_{1}\right.$ and $\left.a_{2}\right)$. They are perceived as images - composite structures made of elementary information pieces. The transformation of one into the other yields further information (possibly even more complex); however we will concentrate only on the colors. Since their transformation is information, they can be viewed as data. Mazur (1970) called the transformation of a datum yielding a different datum a non-banal transformation. Similarly, the transformation yielding an equal datum he called a banal transformation (p. 43). Following this convention, the information $\mathrm{I}_{\mathrm{a} 12}$ is non-banal (two distinct colors are perceived). The observer not only notices the areas, but also identifies their colors $\left\{a_{1}^{\prime}\right.$, $\left.a_{2}^{\prime}\right\}$ as "reddish" and "bluish". This occurs by the comparison of $\left\{a_{1}^{\prime}, a_{2}^{\prime}\right\}$ with the colors learned previously and involves a process of selection. The selection goes on until the matches are found (information $\mathrm{I}_{\mathrm{am} 1}$ and $\mathrm{I}_{\mathrm{am} 2}$ becomes banal).

What happens if the sky is blue all over with no differences to be detected? Then different areas cannot be distinguished as they do not exist (in terms of color). Nevertheless the information is 
processed in the similar manner, but with different results. The information $\mathrm{l}_{\mathrm{a} 12}$ is banal, which means no separate areas in the sky are registered. The process of selection is conducted as previously, and when the information pieces $\mathrm{I}_{\mathrm{am} 1}$ and $\mathrm{I}_{\mathrm{am} 2}$ become banal, it means the matches are found.

It should be noted that in the first case the colors differed, so the observer detected the existence of difference. In the second case the observer detected the existence of sameness.

To summarize what was presented so far:

a) new differences are created in the sensor by the generalization of physical events according to some alphabet; the new differences are at the time of generalization encoded and can be sent as signals along the information channel;

b) in the case of the DVD disk player the differences are already encoded and need no generalization; they are copied by the DVD player and encoded to a different media (laser light, electric impulses, etc.),

c) in the human eye there are also generalization processes and encoding (into electro-chemical signals), so there must exist thesauri; some thesauri process also information of higher dimensions (shapes, colors, etc.),

d) acquisition of new information from the environment is possible not only by "detecting difference", but also by "detecting sameness",

e) in all the cases analyzed the sensors detect the words of their thesauri: as each word is triggered by a physical event, the existence of the event is established.

Before proceeding we must get now to the core of the matter, namely to answer the question which 'being' can be called information. Mazur (1970, p. 70) suggested that it is a transformation (or a relation) between two physical states. Chmielecki (2010, p. 2) said that "Information is closely connected to the process category - it occurs always and only within a process in which it is acquired and which course it directs".

The concept of information as related to process is by no means a new idea. For instance K. Hayles (1999, p. 56) wrote (as cited by R. K. Logan): "Nicholas Tzannes (1968) pointed out that whereas Shannon and Wiener define information in terms of what it is, MacKay defines it in terms of what it does. Both Shannon and Wiener's form of information is a noun or a thing and MacKay's form of information is a verb or process".

However, there is a big difference between the two statements "information is related to process" and "information is a process". Which process is 'information'? Or what entity that can be called 'information' is related to a process?

In order to analyze the problem further, a sound ontology is needed, one that exhausts all possibilities. Such ontology can be found, e.g., in Chmielecki (2001, p. 15), who wrote:

To be something means to belong to one of the ontological categories: to be an object, a property, a relation, a state (of object), a process or an event. Each one of these categories assumes the existence of the preceding one: properties are the properties of an object, relations occur between objects or properties, the state of an object or objects assumes the existence of relations, a process is a change of some state of an object(s), and an event is a phase of a process. In short, the object is a being most self-contained in this series of beings, and the further down the line the less self-contained the beings are.

In the water level control situation (fig.2a) there are two interdependent processes. The first process is that of the water level change. It can be described by a set $L$ of $n$ elements (states or levels), $L=\left\{L_{1}, L_{2}, \ldots L_{c}, \ldots, L_{n}\right\}$. The $L_{c}$ level is the so-called 'set point' of the control device. At it the water level should be kept, so it stands out from among all the other levels. When water rises and the set point is reached (from below), the current is switched on. The set point is also the last level before switching off the current, when the water abates. The set point is the pivot that divides 
the $L$ set into two subset, $N=\left\{L_{1} \ldots L_{c-1}\right\}$ ( $N$ for 'No-flow') and $F=\left\{L_{c} \ldots L_{n}\right\}$ ( $F$ means here 'Flow'). These 'No-flow' and 'Flow' events find their fulfillment in the second process, which is the electric current flow with two voltages. It can be described by a set $U=\left\{U_{0}, U_{C}\right\}$. The $L$ and $U$ sets can be called thesauri. The second process depends on the first one in such a way that for all the states in the L set identical with the $\mathrm{N}$ ('no-flow') subset, the electric current flow is described by the state of the $U_{0}$ voltage (zero voltage, no current flow). For all the other $L$ states, belonging to the $F$ subset, the electric current flow is described by the value of $U_{c}$ (a voltage causing the current to flow).

The following elements should be considered:

- objects: tank, water, sensor (contact), electric circuit,

- processes: water level change (tank process), current change (circuit process),

- states: sets $L=\{N, F\}$ and $U$,

- events: changes between consecutive (neighboring) states within $L$ and $U$,

- properties: specific to the successful technical design of the control device (negligible to this analysis),

- relations: relations within set $\mathrm{L}$, relations within set $\mathrm{U}$, relations between $\mathrm{L}$ and $\mathrm{U}$.

If information is a process then it can be either the tank process or/and the circuit process. Since they are purely physical processes, neither can be called information. It can be argued that these processes consist of more elementary processes, but per force these are purely physical, too. In fact all what happens here can be explained in purely physical terms except for one thing - certain relations in set $L$ are propagated into set $U$. We can take as information a relation between any consecutive two states in the primary process (set L), or/and similarly, a relation between the two states $\left(U_{0}>U_{C}\right.$ and $\left.U_{C} \rightarrow U_{0}\right)$ in the secondary one. Information from the tank process is carried into the circuit process by the way of reflecting in the $U$ set certain relations present in the $L$ set. That means: $(\mathrm{N}->\mathrm{F})=>\left(\mathrm{U}_{0} \rightarrow \mathrm{U}_{\mathrm{C}}\right)$ and $\left.(\mathrm{F}->\mathrm{N})=>\mathrm{U}_{\mathrm{C}} \rightarrow \mathrm{U}_{0}\right)$. In other words, when water begins to touch the contact, the current begins to flow and vice versa.

That the process is not information can be shown in the following way. Let us have a process with two states, say two voltages $\{0 \mathrm{~V}, 1 \mathrm{~V}\}$ and a thesaurus $\{0 \mathrm{~V}, 1 \mathrm{~V}\}$. The relations here are obvious, as far as we deal with two physical processes. Now let us have another thesaurus \{0V, $\infty \mathrm{V}\}$. In this case, although the relations might be obvious, the second process is not feasible. The states of the process can be related only to the symbols used, but not to their meaning. There is no known process that can represent faithfully the meaning of " $\infty \mathrm{V}$ ". And yet such a message can be transmitted over a channel if we agree that the state $1 \mathrm{~V}$ means the symbol " $\infty \mathrm{V}$ ". It is therefore plain that information is not a process, but the relationship between the states of some physical process and the states of some another physical process. If the first process has indeterminable states, it is not so with the second one, the states of which are determined by the relationship with the first process.

\section{From subjective to objective information}

As we have seen, the term information may be used to describe various concepts. There might be some entity called information behind reality as Stonier (1996) presupposed. A theory based on such a proposition would indicate the existence of information that can be called 'absolute' or 'objective'.

However, of the information created in sensors this can be said - it is always unique. According to P. Rocchi $(2010$, p. 9) the creation of information in a sensor relies on the intervention of the sensor in which it singles out an event from its background. The background and the sensor cause double relativism: couple relativity - the impact of the background on the existence of the event, and reference relativity - the impact of the sensor. Thus the information coming into being in a 
sensor is unique (specific to the sensor that creates it and to the conditions that trigger the sensor). Therefore it cannot be called otherwise than 'relative' or 'unique'.

The same is true of receptors (since receptors are in fact human sensors). However, it is necessary to stress the difference in subjectivity between the information acquired by sensors and by receptors. The information acquired by receptors is unique in respect to the environment, the receptors and the person, while the information from sensors is unique in respect to the environment and to the sensors only. To the persons it is objective. Because of this, in the case of sensors the term 'relative' is more appropriate; the term 'subjective' should be reserved for receptors.

Not only elementary information can be subjective, but also complex information structures through which we see the reality - e.g. cognitive schemas are also unique to each person. To exemplify that we can use an example given by M. Bates (2010) who cited Dretske (1981, p. 72):

The acoustic signal that tells us someone is at our door carries not only the information that someone is at the door, but also the information that the door button is depressed, that electricity is flowing through the doorbell circuit, that the clapper on the doorbell is vibrating, and much else besides.

Strictly speaking the acoustic signal carries only the information related to the acoustic characteristics of the signal (duration, frequency etc.). Direction depends e.g. on the position of the sensor relative to the doorbell. Information on the signal (all the properties of the signal perceived) depends on the thesauri of the person's audio receptors - the signal is expressed in the words of the thesauri. The rest of information is taken from the cognitive schemas of the person. The person recognises the sound as the doorbell ring only after comparing it with the information in memory. Somebody, who never heard a doorbell, has no proper cognitive schemas to recognise the sound properly. The interpretation of new information therefore is also subjective.

Nevertheless there are also objective forms of information that originate from subjective information, e.g. scientific theories that can be applied to a broad scope of unique cases. How is subjective information transformed into objective information? Some sources of information 'objectiveness' can be easily indicated. First of all the very generalization of information that takes place at its acquisition "levels" it - the information becomes less unique (averaged information repeats itself in time and space more frequently). For instance, an object seen by two different people from the same spot looks much the same because the generalization conducted is much the same (the thesauri of their receptors are very similar). On some occasions (like the observation of a clear sky) our information channels are in resonance with those of nature and the generalization does not spoil the picture. Another reason is that information can be stored in human memory and kept unchanged for some time (here of course writing has enhanced the process enormously). Similarly it can be copied faithfully (sent and received) in the communication processes. Then, when compared, similarities and differences can be discovered leading to further generalizations - another source of more objective information. A very important source of more objective information is the so-called "epistemic cycle" (Hodgson, 1998), consisting in the verification of information against reality, which is the basis of the scientific method. However, its use is so widespread as to embrace all fields of human activity.

\section{Conclusions}

As we have seen, information is created (in the detectors) by generalization of physical interactions coming from the environment. The encoding of information according to a thesaurus (simple or comprising an alphabet) makes it possible for information to be sent (copied) along information channels. Information can only be expressed in the words of a thesaurus (this follows from the functional principle of a detector). The need for generalization arises from the difference of dimension of the world of particles (micro-world) and our everyday macro-world. Bateson (1979, p. 29) well expressed this idea: "Differences that are too slight or too slowly presented are not perceivable". The selection is done in the detectors if specific conditions occur and because of that information is related to the existence of these conditions. 
The simplest thesaurus has only two words (like the water control circuit in fig.2). The information created from such a thesaurus can be called elementary information because it is the simplest kind of information. There may be cases when two exactly same words are used to create a piece of information. This does not mean that no information is created but that such a piece of information has a special property - it is void, empty, like the zero value in arithmetic. It has its uses though, e.g. in comparing information (as in the case of the detection of blue sky).

Elementary information pieces are used as building blocks of all more complex structures: words and sentences of human languages, Devlin's infons (Devlin, 1991, p. 45), records and tables in databases, objects in object oriented programming languages, features in feature detectors (Maruszewski, 2001, pp. 50-51; Nęcka, Orzechowski \& Szymura, 2008, pp. 283-284), cognitive schemas and mental models. There are myriads of such structures and that might be another reason for so many definitions of information.

Before getting down to the conclusion let us consider if structure (in the sense used in fig.1) is the same as information. Being a relation within some processes, information is 'carried' by an entity. Structure on the other hand can be thought of as an equivalent to form. A DVD contains structures which can represent the same relations as information - thus information can be preserved. Reading a disk in an optical disk drive does not extract information yet, even if the right thesaurus is applied. It has to be used in a process similar in certain aspects to the one in which it was created to extract information.

This can be explained using once more the simple water level circuit (fig. 2a). The information created in the circuit $\left(\mathrm{U}_{0} \rightarrow \mathrm{U}_{\mathrm{C}}\right.$ and $\left.\mathrm{U}_{\mathrm{C}}>\mathrm{U}_{0}\right)$ can be registered in the digital form using a thesaurus $\{0,1\}$. Sent over an information channel it will look like $01010101 \ldots$ - it is only a bare code. If stored on a DVD disk for subsequent use, it will not be useful, because the temporal component is missing (the timing of the events). However, the temporal component is not the component of the code, but of the process in which the information is created. Another component of the same process is called the meaning of information. For instance, the meaning of the information ' $0-1$ ' is "low level reached" and of '1-0' "high level reached". The meaning relates the information to the processes where it is created and where it is used. These processes should be analogous to enable the recreation of the meaning (the meaning of ' $0-\infty$ ' is possible by negation, but that information comes from inference).

It is sometimes stressed that what we see is not the real world, e.g. we distinguish the wavelengths of the light as colors, but the light itself has no color (e.g. Chmielecki, 2001, p. 61). Thinking that things are given us as they are is called naïve realism. And truly it is so, but the matter is not that straightforward. The fact that the water level sensor "sees" the world only through a 'filter of two states' does not mean that it "sees" the world in the wrong way. On the contrary, from the viewpoint of its function it "sees" the world just in the right way. Every human endeavor (or operation or whatever we do) requires certain level of precision. It is necessary to ensure it, but it might be a waste of time and means to try to outdo the necessity. If the water level control system can keep the water level within the acceptable limits, its precision is just fine.

There is also the other side of the coin, when the precision is never sufficient. In fact the purpose of the construction of all measuring devices is to enhance our senses through a better precision. Fig. $6 \mathrm{~b}$ shows that in such cases the precision improvement and the thesauri resolution refinement go hand in hand. In regard to the sensor development and application I strongly believe there is still much work to be done notwithstanding all that has been done till now.

Perhaps some analogy to human cognition of the world can be found in the example of the 'filter of two states'. Although we perceive wavelengths of light as colors, we are good at recognizing colors and that is as much as to be good at recognizing wavelengths of light. It is true that they are given to us indirectly, but another truth is that they are given to us infallibly. That is, once we learn that colors mean wavelengths we can detect them quite infallibly. All this happens by means of information. In my opinion the main role of information (at least that acquired by a detector - sensor or receptor) is to indicate the existence or presence of 'something' (anything that exists and can activate the detector). The existence of 'something' is not given to us directly, but by means of 
information. Information testifies to the existence of that 'something'. In the mind 'something' exits as information (i.e. the information represents that 'something'). Therefore a definition of information could be: "information (acquired from detectors) is the carrier of existence".

The evidence of information that indicates the existence of 'something' is not infallible. "Sometime something goes wrong" and then disinformation comes into existence. Or it may be introduced intentionally. The problem of disinformation and misinforming was studied by Mazur (1970, pp. 141-152). An in-depth study of these matters was conducted by Burgin (2005).

Derived information (from inference) can also indicate the existence of something, and there are spectacular examples of how such information led in science to great discoveries. M. Tempczyk (2005) quoted such cases as the discovery of the planets Neptune and Pluto (p. 159) or the determination of the existence of black holes (p. 67).

The information we acquire from sensors is relative because of the way of acquisition. The information from receptors is subjective because of the way it is used (it becomes the sole property of the person who owns the receptors). However, it can be made objective by such ways as communication and validation (of which a very important way is the verification through experimentation).

\section{References}

Alleman, G. A. (2000). How DVDs work. HowStuffWorks.com. Retrieved from http://electronics.howstuffworks.com/dvd.htm

American Society for Cybernetics. (2008). History of cybernetics. Summary: The Macy conferences. Retrieved from http://www.asc-cybernetics.org/foundations/history/MacySummary.htm

Bates, M. J. (2006). Fundamental forms of information. Journal of the American Society for Information Science and Technology, 57(8), 1033-1045. Retrieved from http://gseis.ucla.edu/faculty/bates/articles/NatRep_info_11m_050514.html

Bates, M. J. (2010). Information. In Bates M. J., \& Maack M. N. (Eds.). Encyclopedia of library and information sciences. (Vol. 3, 3rd ed., pp. 2347-2360). New York, NY: CRC Press. Retrieved from http://gseis.ucla.edu/faculty/bates/articles/information.html

Bateson, G. (1972). Steps to an ecology of mind: Collected essays in anthropology, psychiatry, evolution, and epistemology. Northvale, NJ, London: Jason Aronson Inc.

Bateson, G. (1979). Mind and nature: A necessary unity. New York, NY: E. P. Dutton.

Błasiak, Z. A., \& Koszowy, M. (2010). Informacja. In Powszechna encyklopedia filozofii. Lublin: Polskie Towarzystwo Tomasza z Akwinu, Katedra Metafizyki KUL. Retrieved from http://www.ptta.pl/pef/pdf/i/lnformacja.pdf

Bekenstein, J. D. (2003, August). Information in the holographic universe. Scientific American Magazine.

Burgin, M. (2003). Information theory: A multifaceted model of information. Entropy, 5(2), 146-160.

Burgin, M. (2005). Is information some kind of data? In Petitjean, M. (Ed.). Proceedings from FIS2005: The Third Conference on the Foundations of Information Science. Basel: MDPI. Retrieved from http://www.mdpi.org/fis2005

Burgin, M. (2010). Theory of information. Fundamentality, diversity and unification. Singapore: World Scientific Publishing.

Capurro, R. (2009). Past, present, and future of the concept of information. TripleC, 7(2), 125-141.

Chmielecki, A. (1998). What is information? In Olson A. M. (Ed.). Proceedings from 20th WCP: Twentieth World Congress of Philosophy. Boston, MA: Paideia Project On-Line. Retrieved from http://www.bu.edu/wcp/Papers/Cogn/CognChmi.htm

Chmielecki, A. (2001). Między mózgiem i świadomością. Próba rozwiązania problemu psychofizycznego. IFiS PAN. Retrieved from http://www.ifsid.ug.gda.pl/filozofia/pracownicy/chmielecki-mozg-swiadomosc.pdf

Chmielecki, A. (2010). Ontologiczne pojęcie informacji i jego zastosowania. Cz. I. Poznań: Questions of Boundaries Research Group, Adam Mickiewicz University. Retrieved from http://www.graniczne.amu.edu.pl/PPGWiki/wiki/InformacjaNagrania

Devlin, K. (1991). Logic and information. Cambridge: Cambridge University Press.

Díaz Nafría, J. M. (2010). What is information? A multidimensional concern. TripleC, 8(1), 77-108.

Dretske, F. I. (1981). Knowledge and the flow of information. Cambridge, MA: MIT Press.

Farabee, M. J. (1992). The nervous system. Avondale, AZ: Estrella Mountain Community College. Retrieved from http://www2.estrellamountain.edu/faculty/farabee/biobk/BioBookNERV.html

Floridi, L. (2004). Open problems in the philosophy of information. Metaphilosophy, 35(4), 555-583.

Flückiger, D. F. (1995). Contributions towards a unified concept of information. (Doctoral disseration). Berne: University of Berne. Retrieved from http://citeseerx.ist.psu.edu/viewdoc/download?doi=10.1.1.91.4428\&rep=rep1\&type=pdf 
Fuchs, C. A. (2003). Quantum mechanics as quantum information, mostly. Journal of Modern Optics, 50(6-7), 987-1023.

Gackowski, Z. J. (2010). Subjectivity dispelled: Physical views of information and informing. Informing Science: The International Journal of an Emerging Transdiscipline, 13, 35-52. Retrieved from http://inform.nu/Articles/Vol13/ISJv13p035-052Gackowski559.pdf

Gleitman, H. (1991). Psychology. New York, NY: Norton.

Gorshkov, V. V., Gorshkov, V. G., Danilov-Danilyan, V. I., Losev, K. S., \& Makareva, A. M. (2002). Information in the animate and inanimate worlds. Russian Journal of Ecology, 33(3), 149-155.

Hayles, N. K. (1999). How we became posthuman. Virtual bodies in cybernetics, literature, and informatics. Chicago, IL: University of Chicago Press.

Hodgson, P. (1998). The nature of belief. In Science and belief (chapter 1). Cromwell, CT: International Catholic University. Retrieved from http://home.comcast.net/ icuweb/c02301.htm

Jaros, M., \& Pabis, S. (2007). Inżynieria systemów. Warszawa: Wydawnictwo SGGW.

Kaiser, P. K. (2009). The joy of visual perception: A web book. Toronto: York University. Retrieved from http://www.yorku.ca/eye/

Kolb, H. (2003, January-February). How the retina works. American Scientist, 91, 28-35. Retrieved from http://www.americanscientist.org/issues/feature/how-the-retina-works

Kolb, H., Fernandez, E., \& Nelson, R. (2010). Webvision. The organization of the retina and visual system. Salt Lake City, UT: University of Utah. Retrieved from http://www.webvision.med.utah.edu/

Kowalczyk, E. (1981). O istocie informacji. Warszawa: WKit.

Lenski, W. (2010). Information: A conceptual investigation. Information 1, 74-118.

Logan, R. K. (n.d.). What is information? Why is it relativistic? And what is its relationship to materiality, meaning and organization? In What is information? - Propagating organization in the biosphere, the symbolosphere, the technosphere and the econosphere (chapter 2). Retrieved from http://www.physics.utoronto.ca/people/homepages/logan

Maruszewski, T. (2001). Psychologia poznania. Gdańsk: GWP.

Mazur, M. (1966). Cybernetyczna teoria układów samodzielnych. Warszawa: PWN. Retrieved from http://www.autonom.edu.pl/publikacje/mm-ctus/marian_mazur-cybernetyczna_teoria_ukladow_samodzielnych.html

Mazur, M. (1970). Jakościowa teoria informacji. Warszawa: WNT. Retrieved from http://www.autonom.edu.pl/publikacje/mm-jti/marian_mazur-jakosciowa_teoria_informacji.html

Mazurek, L. (2001). Modelowanie początkowych etapów przetwarzania informacji wzrokowej. (Master thesis). Kraków: Akademia Górniczo-Hutnicza im. Stanisława Staszica. Retrieved from http://195.117.188.199/pdf/praca.pdf

Michałowski, A. (2007). Informacja w ekosystemach. Białystok: Agencja Wydawniczo-Edytorska EkoPress.

Mulder, D. H. (2004). Objectivity. In The Internet encyclopedia of philosophy. Retrieved from http://www.iep.utm.edu/

Nęcka, E., Orzechowski, J. \& Szymura, B. (2008). Psychologia poznawcza. Warszawa: PWN.

Rocchi, P. (2010). Notes on the essential system to acquire information. Advances in Mathematical Physics, 2010, Article ID 480421. doi: $10.1155 / 2010 / 480421$

Saab, D. J., \& Riss, U. V. (n.d.). Information as ontologization. Retrieved from http://www.djsaab.info/writing/saab_riss_information_as_ontologization_v09.2_20101124.pdf

Schrader, A. M. (1983). Toward a theory of library and information science. (Unpublished doctoral dissertation). Bloomington, IN: UMI Dissertation Information Service, Indiana University.

Steup, M. (2005). Epistemology. In Zalta E. N. (Ed.). The Stanford encyclopedia of philosophy (Spring 2010 edition). Retrieved from http://plato.stanford.edu/archives/spr2010/entries/epistemology/.

Shannon, C. E. (1948). A mathematical theory of communication. The Bell System Technical Journal, 27, 379-423, 623656. Retrieved from http://cm.bell-labs.com $/ \mathrm{cm} / \mathrm{ms} /$ what $/$ shannonday/shannon1948.pdf

Stonier, T. (1996). Information as a basic property of the universe. Bio Systems 38, 135-140.

Tempczyk, M. (2005). Ontologia świata przyrody. Kraków: Universitas.

Weizsäcker, C. F. von. (1978). Materia, energia, informacja. In Jedność przyrody (part 3, chapter 5). K. Napiórkowski, J. Prokopiuk, H. Tomasik \& K. Wolicki (Trans.). Warszawa: Państwowy Instytut Wydawniczy. (Original work published 1971). Retrieved from

http://www.graniczne.amu.edu.pl/PPGWiki/attach/InformacjaMateria\%C5\%82y/Weizsaecker2.pdf

Wiener, N. (1948). Cybernetics or control and communication in the animal and the machine. New York, NY: Wiley.

Young, P. (1987). The nature of information. New York, NY: Praeger Publishers.

Zins, C. (2007). Conceptual approaches for defining data, information, and knowledge. Journal of the American Society for Information Science and Technology, 58(4), 479-493. 


\section{About the Author}

Andrzej Stanisław Zaliwski

Born in 1951 in Puławy, Poland. Ph.D. in Technical Sciences at the University of Life Sciences (ULS) in Lublin, 1983, Thesis: Mechanization of French bean harvest). He is currently DSS specialist at the Institute of Soil Science and Plant Cultivation (ISSPC) in Puławy, Poland. He earned an M.A. in Agricultural Engineering (1975) from Slovak Agricultural University in Nitra, Slovakia. From 1975 to 1987 he worked at ULS as academic teacher and from 1988 to 1995 as researcher at the Special Crops Department at ISSPC. He was Head of the Applied Mathematics and Informatics Department in 1995-2000 and Head of the Agrometeorology and Applied Informatics Department in 2000-2004, both at ISSPC. He has authored or co-authored over 60 scientific articles and co-authored a number of information systems and decision support systems. 